\title{
Potential and Risk of Grouper (Epinephelus spp., Epinephelidae) Stock Enhancement in Indonesia
}

\author{
Irfan Yulianto ${ }^{1,3 *}$, Cornelius Hammer ${ }^{2}$, Budy Wiryawan ${ }^{3}$ and Harry W Palm ${ }^{1}$ \\ ${ }_{1}^{1}$ University of Rostock, Aquaculture and Sea-Ranching, Justus-von-Liebig Weg 6, 18059 Germany \\ ${ }^{2}$ Thünen-Institute of Baltic Sea Fisheries Rostock, Alter Hafen Süd 2, 18069 Rostock, Germany \\ ${ }^{3}$ Bogor Agricultural University, Faculty of Fisheries and Marine Sciences, Kampus IPB Darmaga, Bogor, Indonesia
}

\begin{abstract}
Indonesia is one of the countries in Asia region that plays an important role in the grouper supply. Grouper production in Indonesia increased 5-fold within two decades aside a continuous increase in grouper demand. To enhance grouper yield, the Indonesian Government initiated stock enhancement programmes releasing cultured grouper into the natural habitats. The purpose of the present study was to examine the impact of grouper stock enhancement onto natural grouper populations in Karimujawa National Park, Indonesia and to monitor the potential risks involved. Experimental release of $10 \mathrm{~cm}$ cultured Epinephelus fuscoguttatus (brown-marbled grouper) from the backyard multi-species hatchery system was monitored using underwater visual census and fish-catch monitoring. As a result, it was found that the greatest peril for the released grouper of $10 \mathrm{~cm}$ length was falling immediately prey to predators in the reef habitat, even though enough places to hide were available at the release site, since groupers of this particular size class were not trained to survive under field conditions. However, groupers of $15 \mathrm{~cm}$ are well capable of seeking shelter and avoiding predators. This leads to the clear recommendation that released grouper should have a size of at least $15 \mathrm{~cm}$ for release in stock enhancement programmes. According to our experiments, the prior officially recommended minimum size of release $(10 \mathrm{~cm})$ is too low and has to be increased to $15 \mathrm{~cm}$ for $E$. fuscoguttatus, and requires future adjustment of the official recommendations in use. Parasitological examination of the released fish was conducted in order to analyse potential risks involved. No macro-parasites could be observed, limiting the risk of spreading parasites and diseases within the Indonesian archipelago. However, many parasites of E. fuscoguttatus are widespread and can infect different grouper species.
\end{abstract}

Keywords: Epinephelus fuscoguttatus; Grouper fishery; Indonesia; Karimunjawa National Park; Stock enhancement; Wild-caught grouper

\section{Introduction}

Groupers belong to the high valuable Asian fish commodities, 80 $\%$ of the world grouper production in 2008 originates from the region [1]. Based on the Food and Agriculture Organization of the United Nations [2], the total production of grouper increased $25 \%$ between 1999 and 2009, and more than 17 times between 1950 and 2009 [1]. Indonesia plays an important role in grouper supply [3-4]. According to the fisheries statistics [5], grouper production in Indonesia was 15,786 $\mathrm{t}$ in 1990 and increased to more than the double in 2000, reaching $48,422 \mathrm{t}$ (Figure 1). In 2012, grouper production reached 92,183 t

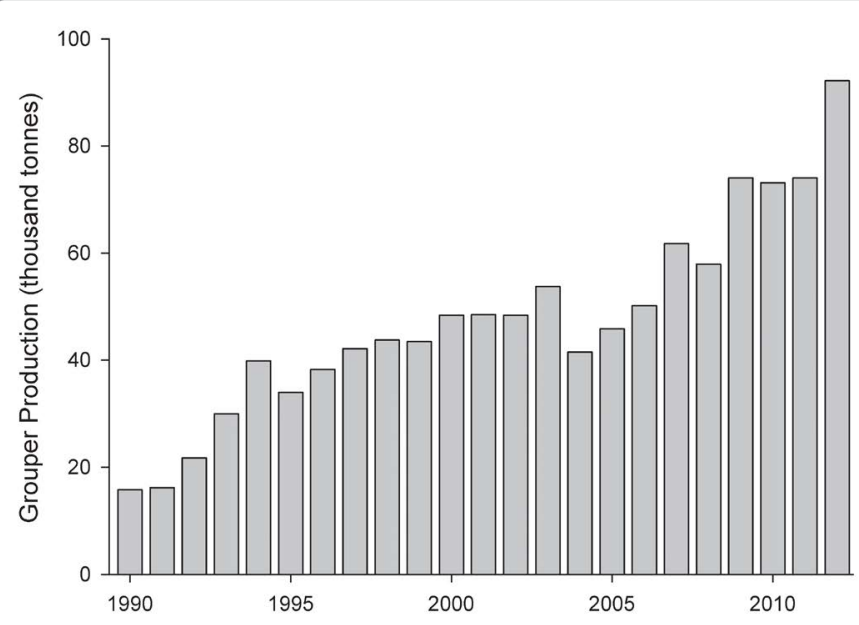

Figure 1: Captured grouper production in Indonesia (kg) from 1990 to 2012. or increased more than 5 times in two decades [6]. The Indonesian Government announced a new and ambitious policy for the fisheries sector to increase the fish production by more than $300 \%$ until 2015 [7], making Indonesia becomes the world's largest fish producer. Several programmes have been implemented to realize the new policy, e.g. aquaculture intensification, establishment of marine protected areas, and fish stock enhancement programmes, the latter included the release of cultured fish into the natural populations.

According to Bell et al. [8], the release of cultured fish into the natural populations falls into three categories, i.e. restocking, stock enhancement, and sea ranching. Restocking is the release of cultured fish into the natural population to recover fish populations that are in depleted condition. Stock enhancement is the release of cultured fish into the natural populations to enhance the supply of juveniles. Sea ranching is the release of cultured fish into unenclosed areas to harvest later, with definite benefit for releasing company or institution. Stock enhancement was introduced in 1762 for freshwater fish and implemented for marine fish the first time in 1962, both in Japan [9]. In 1990s, the number of countries implementing marine

*Corresponding author: Irfan Yulianto, University of Rostock, Aquaculture and Sea-Ranching, Justus-von-Liebig Weg 6, 18059 Germany. Email: irfan.yulianto@uni-rostock.de

Received October 29, 2014; Accepted December 06, 2014; Published January 13, 2015

Citation: Yulianto I, Hammer C, Wiryawan B, Palm HW (2015) Potential and Risk of Grouper (Epinephelus spp., Epinephelidae) Stock Enhancement in Indonesia. J Coast Zone Manag 18: 394. doi: 10.4172/2473-3350.1000394

Copyright: ( $) 2015$ Yulianto I, et al. This is an open-access article distributed under the terms of the Creative Commons Attribution License, which permits unrestricted use, distribution, and reproduction in any medium, provided the original author and source are credited. 
fish stock enhancement raised [8], including successful stories such as the southern scallop fishery enhancement in New Zealand [10], shrimp (Penaeus esculentus) stock enhancement in Western Australia [11], and salmon [9], and other finfish [12] stock enhancement in Japan. However, several lessons learned were reported, providing input to future stock enhancement programmes especially related to the science, methodology and techniques involved [8]. The most prominent risks and problems that probably arise and should be avoided occur after the release of the cultured fish concerning the fish adaptation to the new habitat [13], parasites that probably are transferred from the culture facility [14], and strong fisheries exploitation before the fish reach suitable market size [15].

Prior to 2010, the release of cultured fish for stock enhancement in Indonesia was only known for freshwater fish. In 2010, the Ministry of Marine Affairs and Fisheries initiated a stock enhancement programme for marine fish called "one man one thousand fries" including groupers. Other institutions also started similar activities, i.e. the District Government of the Seribu Islands in collaboration with the Centre of Coastal and Marine Research Study-Bogor Agricultural University in Seribu Islands and Karimunjawa National Park Authority in Karimunjawa Islands. There are only few studies with impact via stock enhancement in Indonesia especially for marine species, such as squid stock enhancement by squid attractor [16], napoleon wrasse stock enhancement by artificial reef [17], sea cucumber stock enhancement [18] and grouper sea ranching [19]. Apparently, there is only one study employing a model of grouper stock enhancement in Indonesia based on the biological information [19], however, studies on the potential of these activities and the risks involved are still missing.

The objective of this study was to examine the impact of grouper stock enhancement, including a success monitoring and recommendations for future stock enhancement activities in the region. An experimental release of aquaculture produced Epinephelus fuscoguttatus into their natural coral reef habitat was conducted and monitored. The juveniles were studied for fish parasites before the release. The future potential of grouper stock enhancement and potential risks involved are discussed.

\section{Materials and Methods}

\section{Study site}

Karimunjawa Islands with around 9000 inhabitants belong to Jepara District, and are located in the Java Sea, $79 \mathrm{~km}$ north of Java Island. Five tropical ecosystems can be found in these islands; low land forest, mangrove, beach vegetation, seagrass, and coral reef [20]. Grouper demand in these islands is estimated to be $3000 \mathrm{~kg}$ per year, but the fishermen cannot fulfil the demand [21]. In 1999, the Indonesian Ministry of Forestry designated 22 of 27 islands as Karimunjawa National Park. To manage the park, the National Park is divided into a core zone, protected zone, tourism zone, rehabilitation zone, aquaculture zone, and a traditional fisheries or utilisation zone. The core zones and the protected zones are the areas of highest protection and are dedicated to ensure the grouper resources, which including the grouper spawning aggregation site [22].

\section{Grouper Release}

Groupers were bought from Jepara, the nearest place of mariculture facility that was able to provide the fingerlings which were reared by the backyard multi-species hatchery system. Groupers were bought two weeks before the release time, and adapted within a net cage to the local conditions in Karimunjawa Islands. Four days before the release, fingerling of Epinephelus fuscoguttatus, Forsskål, 1775 were tagged with T-bar extra small anchor FF-94 tags (Floy Tag) of 38.1 $\mathrm{mm}$ length. The tags were inserted by a pistol grip into the dorsal musculature of the fish. One day before release, the fish were not fed to prevent transportation mortality. The tagging mortality was $1.01 \% ; 15$ of 1482 fish died in net cage probably due to the first transport or tagging process, and 35 fish (2.36\%) died due during boat transportation from the net cage to Taka Malang.

On November $27^{\text {th }}, 2012,1432$ cultured brown-marbled groupers were released into two sites; 623 tagged fish were released in Taka Malang and 809 tagged fish were released in Cemara Kecil Island. The size of the released grouper was $10 \mathrm{~cm}$ as it is the common available size of fingerling grouper in mariculture centre, and the minimum size of grouper for stock enhancement recommended by Kurnia [19] and MMAF [23]. Kurnia [19] assumed that groupers of $10 \mathrm{~cm}$ can survive in nature. Taka Malang is the core zone or the no-take zone and Cemara Kecil Island is the protected zone in the National Park. Apart from research and education with prior permit, no activity is allowed in Taka Malang, and fishing activities are not allowed in Cemara Kecil Island. Taka Malang is a patchy reef complex and located close to the main land of Karimunjawa Island. Taka Malang is indicated as a spawning aggregation site for grouper [24], and is an open area; we assumed that the cultured fish is able to migrate to other areas. Based on the underwater visual census survey in 2012, the grouper biomass in Taka Malang was $40.6 \mathrm{~kg} \mathrm{ha}^{-1}$ with the greatest fish size in the range of $20-25 \mathrm{~cm}$.

Cemara Kecil Island is a small island in the western part of Karimunjawa Island, surrounded by coral reef and can be considered a semi-closed area. We assumed that the released fish has limited migration areas. In Cemara Kecil Island, grouper biomass in 2012 was $10.1 \mathrm{~kg} \mathrm{ha}^{-1}$ with the largest fish size between 15 and $20 \mathrm{~cm}$. Reef fish biomass in the marine protected area can reach $1200 \mathrm{~kg} \mathrm{ha}^{-1}$ [25]. Assuming that about $10 \%$ are grouper, then grouper biomass can reach $120 \mathrm{~kg} \mathrm{ha}^{-1}$. This value is close to the highest grouper biomass found in the marine protected area of $130 \mathrm{~kg} \mathrm{ha}^{-1}$ [26]. Comparing the grouper biomass that can be reached in the marine protected area with the grouper biomass in Taka Malang and Cemara Kecil Island, it should be possible to enhance the stock of grouper at both release sites.

After the release of fish, we conducted meetings with fishermen and sent a message via "short message service blast" to disseminate the information on the stock enhancement programme to fishermen and the community. The meetings were conducted twice with more than 50 fishermen and their community and the messages were sent twice to more than 1000 phone numbers of fishermen and the community in Karimunjawa Islands. Besides the meetings and the short messages, we also informed the fishermen when we met them and had informal discussion. In the meetings, discussions and messages, we informed about the grouper release as part of the stock enhancement programme; we requested the fishermen not to catch the tagged fish until the suitable size, and to inform us when they accidentally caught fish with tags. We also informed them that they would be rewarded by the double regular price of fish if they caught the fish after May 2013 or when the fish had reached a weight of $0.25 \mathrm{~kg}$.

\section{Underwater Monitoring}

Underwater monitoring was conducted to study the grouper distribution and change of abundance in the natural population. The method used in the surveys was underwater visual census with timed swim and belt-transect technique according to Campbell and Pardede [27] and Yulianto et al. [28] as well as Yulianto 
et al. [29] for fish total length estimate. The timed swim technique covered an area of about $300 \mathrm{~m} \times 100 \mathrm{~m}$, the divers started from the surface, diving to the bottom of the reef and then returned to the shallow for 60 minutes where most of the swim time (30 minutes) was spent. For the Belt transect technique, the divers recorded the size of all groupers along three $50 \mathrm{~m}$ transects at reef crest and reef slope at each site. The surveyed transects were $2 \mathrm{~m}$ wide for $\mathrm{fish}<=10 \mathrm{~cm}$ and 5 $\mathrm{m}$ wide for fish $>10 \mathrm{~cm}$.

The surveys were conducted every day in the first week, every ten days in the first month, the third of month, and the sixth of month after the release of the grouper. The belt transect surveys were conducted in December 2012 and in May 2013. In December 2012, we conducted belt transect survey Taka Malang and Cemara Kecil Island. In May 2013, we conducted belt transect survey at 43 sites of the reef crests and reef slopes in all of reef areas of Karimunjawa Islands which was included Taka Malang and Cemara Kecil Island. The divers recorded the number and size of the total length of grouper with tags and without any tags. Moreover, the divers also observed the behaviour of the released and tagged fish in the natural environment in the first week after the release. Based on this preliminary finding on the behaviour of the released and tagged fish, we attempted to find larger brown-marbled grouper from mariculture in Karimunjawa Islands in order to release and observe their adaptation as well. We could only purchase 35 cultured browmarbled groupers of $15 \mathrm{~cm}$ total length and released them on June $26^{\text {th }}$, 2013 in Cemara Kecil Island.

\section{Fish-catch Monitoring}

Fish-catch monitoring was divided into two types of monitoring; fish-catch monitoring for landed dead fish ("fish landing survey") and fish-catch monitoring for live grouper catches ("live grouper catch survey"). Fish-catch monitoring was conducted from January 2013 for 15 days every month during new moon phase, since few or no fishermen went out fishing during the full moon phase. The fish landing survey was conducted in Karimunjawa Island with the largest landing site. Live grouper catch survey started in March 2013 due to bad weather in January and February 2013. As fishermen are not allowed to fish at the release sites in the no-take zone and protected zones, we operated traps to catch grouper in the release sites. Three traps were operated at each site in March, April, and June 2013. For groupers caught by trap and from fish landing survey, the total length and total weight per fish were recorded. During live grouper catch surveys; we only recorded the number of fish and weight of grouper. Grouper caught alive were directly sold to a fish collector and/or placed into the net cage. For this reason, it was not possible to measure the total length of the fish. The weight of live grouper catches was calculated based on the trading receipts or fishermen estimation.

The Catch Per Unit Effort (CPUE) of brown-marbled grouper was calculated per year for the fish landing survey and per month for the live grouper catches survey. The CPUE from fish the landing survey was compared with the CPUE of each fishing gear from the fish landing surveys in 2011 and 2012. The fish landing data in 2011 and 2012 were collected from Karimunjawa National Park reef fish database, under the Karimunjawa National Park Authority and Wildlife Conservation Society Program. Independent $t$-tests were conducted to compare the CPUEs. We compared the CPUEs of live brown-marbled grouper catches each month and analysed the fishing ground of brown-marbled grouper.

\section{Parasite Investigation}

Parasite investigation was conducted to investigate the parasites in

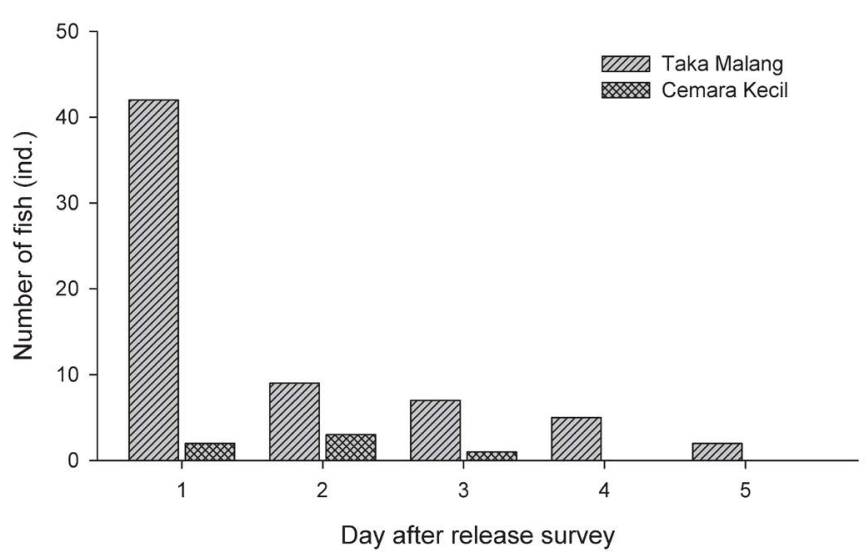

Figure 2: Numbers of released (ind.) cultured grouper that were found during the timed swim survey.

the cultured brown-marbled groupers that were released to the natural population. Thirty-five cultured groupers were randomly chosen and frozen at $-20^{\circ} \mathrm{C}$ until subsequently dissected in the laboratory. In the laboratory, we examined the ectoparasite from the skin, fins, eyes, gills, mouth- and gill-cavity, and the endoparasite in the inner organs; digestive tract, liver, gall bladder, spleen, kidneys, heart and swim bladder. The inner organs were separated into different petri dishes with saline solution and investigated under a Zeiss Stemi DV4 binocular microscope [30]. The gut wash and body soak method [31] were also used for a complete investigation. The isolated parasites were preserved in $70 \%$ ethanol. To identify the parasite species, we transferred the parasite from graded ethanol to $100 \%$ glycerine [32]. We analyse the parasite by calculating the prevalence of infection.

\section{Results}

\section{Underwater Monitoring}

During timed swim survey at both release sites, we only recorded cultured brown-marbled grouper during the first five days. The first day after the release, we found 42 tagged brown-marbled groupers in Taka Malang and 2 tagged groupers in Cemara Kecil Island. The second day 9 brown-marbled groupers were found in Taka Malang and 3 in Cemara Kecil Island. Third day, 7 and 1 tagged groupers were found in Taka Malang and Cemara Kecil Island respectively. The fourth and fifth day, 5 and 2 tagged groupers were recorded only for Taka Malang (Figure 2). The groupers found during the first three days were within a $3 \mathrm{~m}$ radius from the release site. The fourth day, the maximum distance from the release site was $10 \mathrm{~m}$. During belt transect surveys, we did not find any brown-marbled grouper, even though we have used 258 of the 50 meters line transects to survey brown-marbled grouper in all of reef areas within Karimunjawa Islands.

Based on the observation of the brown-marbled grouper in their natural environment, we found that the cultured grouper did not quickly adapt to the natural conditions. After the release, the cultured grouper laid themselves on the bottom of the release site and did not swim to a shelter in the coral reef formation to hide from potential predators. Moreover, they also did not flee when they were approached by bigger sized of groupers, thus they were easy prey. Figure 3 demonstrates the process of bigger size grouper preying upon the cultured grouper. Only during the second or third day, the released grouper started to adapt to the natural conditions, hiding themselves in the coral reef 
Citation: Yulianto I, Hammer C, Wiryawan B, Palm HW (2015) Potential and Risk of Grouper (Epinephelus spp., Epinephelidae) Stock Enhancement in Indonesia. J Coast Zone Manag 18: 394. doi: 10.4172/2473-3350.1000394

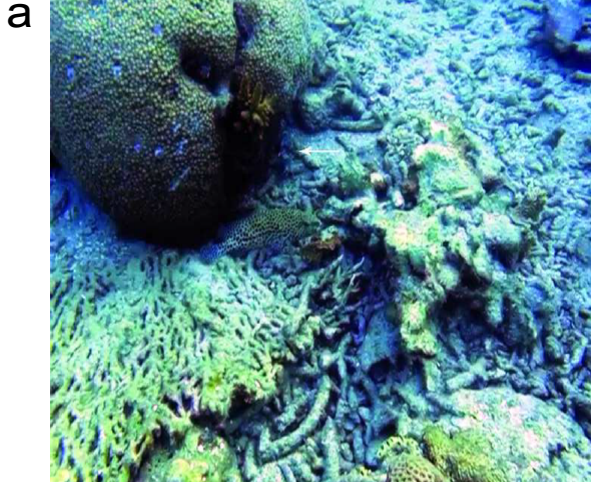

b

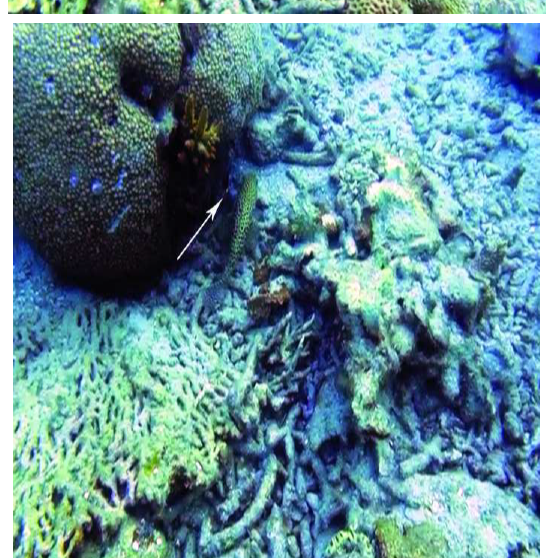

C

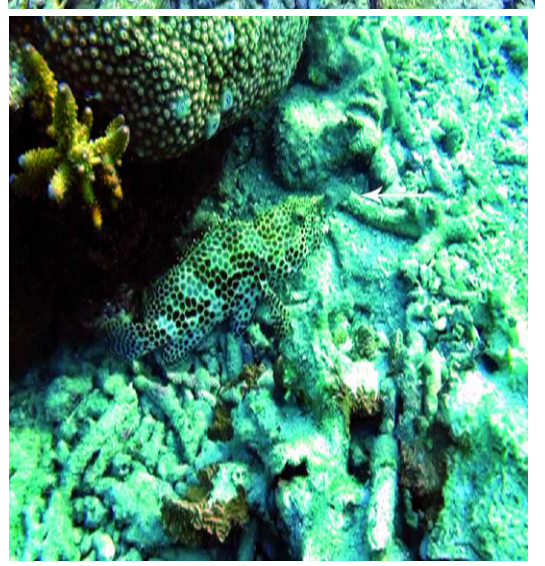

Figure 3: (a). Predation of cultured grouper by another grouper; Larger grouper noticed the cultured grouper that did not move (white arrow indicates the position of the cultured grouper with a tag).

(b). Predation of cultured grouper by another grouper; Larger grouper approached the cultured grouper and the cultured grouper still did not move (white arrow indicates the position of the cultured grouper with a tag).

(c). Predation of cultured grouper by another grouper; the cultured groupe was eaten by the larger grouper (white arrow indicates the position of cultured inside the larger grouper mouth).

formation. However, they were too weak to defend their hiding spot and rather swam away when other similar sized fish approached them or when similar sized wrasse fish bit the tags.

Based on the observation of larger cultured brown-marbled grouper in their natural environment after the release, the cultured grouper of $15 \mathrm{~cm}$ directly adapted to the natural conditions. After the release, they swam directly to the caves of the coral reef formation, and after one hour, they were not detectable anymore and remained undetectable in the process. This leads to the assumption that bigger sized fish directly adapted to the natural conditions and was able to hide themselves in the coral reef formations more effectively.

\section{Fish-catch Monitoring}

We only received three reports on recaptured brown-marbled grouper. The first report of recapture was received at the end of December 2012 or one month after the release. A tourist guide accidently speared a tagged brown-marbled grouper when he accompanied visitors to Cemara Kecil Island and speargunned in the shallow water of the seagrass. The second report of recapture was also received the end of December 2012. A grouper with tag was caught by speargun fisherman in the deep reef outside of the protection zone in Cemara Kecil Island. We received the third report in March 2013, a brown-marbled grouper with tag that was caught by trap in deep reef of Cemara Kecil Island, and the fisherman released the fish again. Moreover, we also caught once a brown-marbled grouper in Cemara Kecil Island while we operated the traps at the release site in March, April, and June 2013, but this grouper was not a released one.

During fish landing survey, the catch per unit effort of speargun and trap in 2013 was $0.196(\mathrm{SE}=0.091) \mathrm{kg}$ trip $^{-1}$ and $0.050(\mathrm{SE}=0.037)$ $\mathrm{kg}$ trip $^{-1}$, respectively. It was higher than CPUE for both fishing gears in 2012 where no brown-marbled grouper was caught. CPUE of Speargun in 2011 was also significantly lower $(p<0.05)$ than CPUE in 2013, it was only $0.034(\mathrm{SE}=0.034) \mathrm{kg}_{\mathrm{rip}}{ }^{-1}$. There was no brown-marbled grouper caught by handline in 2013, and the CPUE of handline in 2011 and 2012 was very low; it was only $0.003(\mathrm{SE}=0.003) \mathrm{kg} \mathrm{trip}^{-1}$ in 2011 and 0.008 $(\mathrm{SE}=0.008) \mathrm{kg} \mathrm{trip}^{-1}$ in 2012 (Figure 4). Although CPUE of speargun

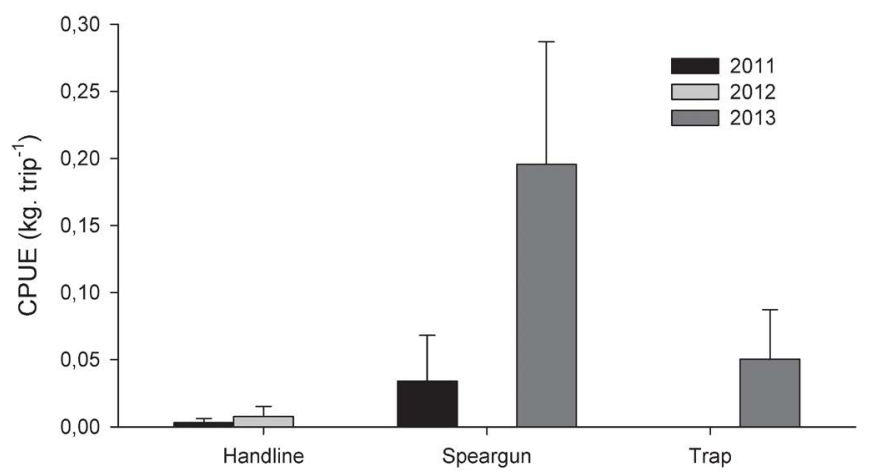

Figure 4: Catch per unit effort $\left(\mathrm{kg}\right.$. trip $\left.^{-1} \pm \mathrm{SE}\right)$ of brown-marbled grouper from fish landing survey.

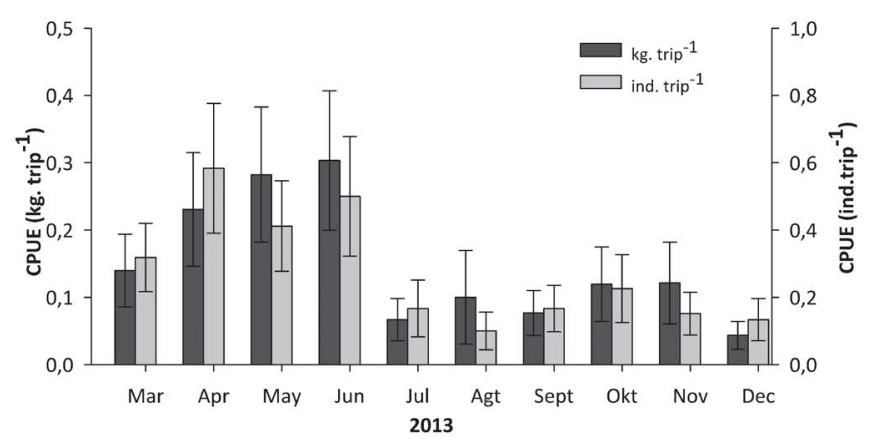

Figure 5: Catch per unit effort (kg. trip ${ }^{-1} \pm S E$ and ind. trip $\left.{ }^{-1} \pm S E\right)$ of brownmarbled grouper from live grouper catch. 
Citation: Yulianto I, Hammer C, Wiryawan B, Palm HW (2015) Potential and Risk of Grouper (Epinephelus spp., Epinephelidae) Stock Enhancement in Indonesia. J Coast Zone Manag 18: 394. doi: 10.4172/2473-3350.1000394
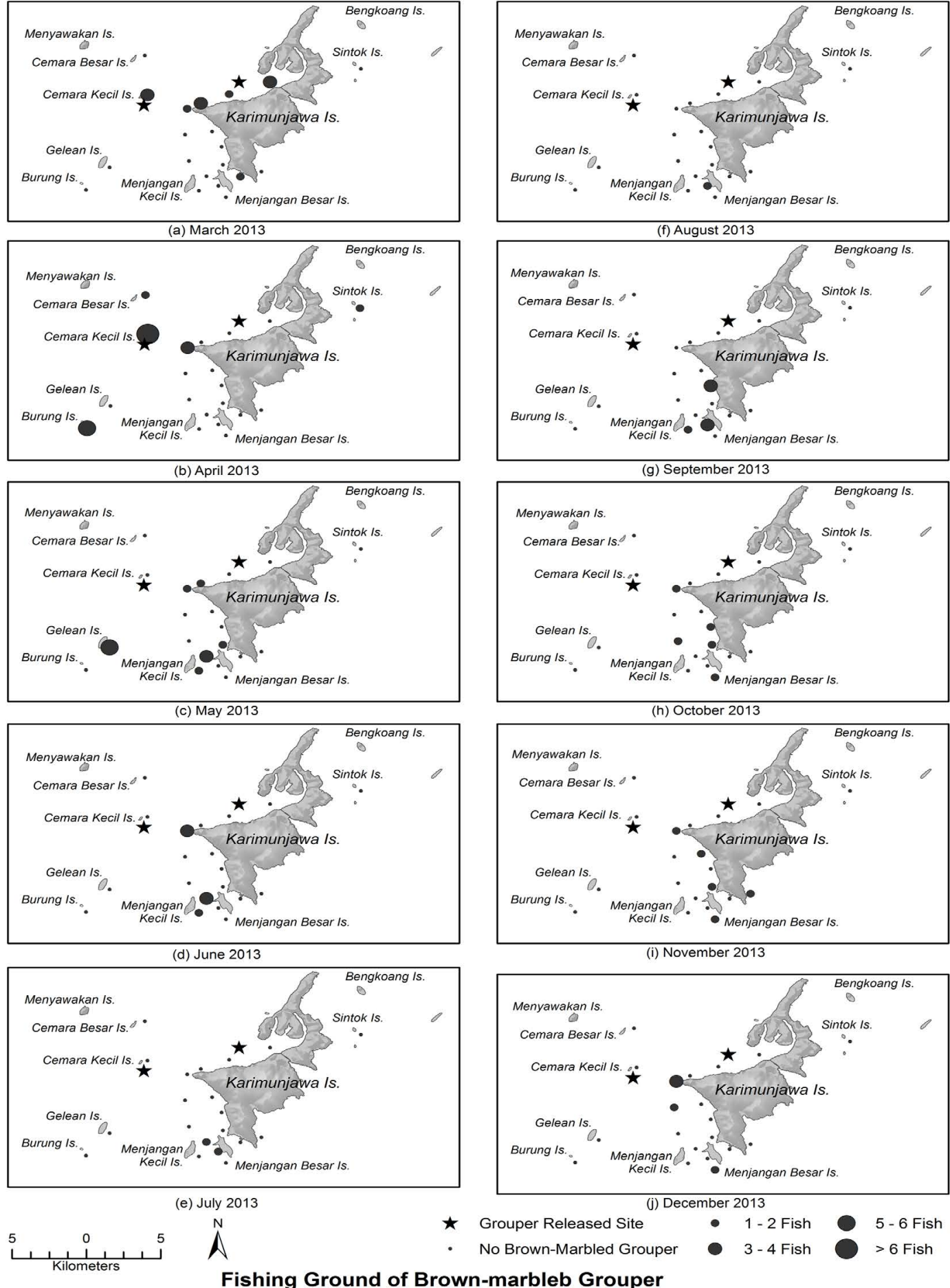

- 1 - 2 Fish

Fishing Ground of Brown-marbleb Grouper

Figure 6: Fishing ground of trap that caught live grouper from March to December 2013.

and trap in 2013 was higher than CPUE of both fishing gears in 2012, it is assumed that it was not an effect of the stock enhancement since no a single tagged brown-marbled grouper was recorded (if not tags were lost). During the live grouper catch survey where fishermen only used traps to catch live grouper, high CPUE was recorded in March, April, May, and June 2013. The highest CPUE in weight was recorded in June 2013 , it reached $0.30(\mathrm{SE}=0.10) \mathrm{kg}$ trip $^{-1}$. The highest CPUE in number of fish was recorded in April, it reached $0.58(\mathrm{SE}=0.19)$ ind trip ${ }^{-1}$. In July 2013, the CPUE of live grouper decreased dramatically to 0.07 (SE $=0.03) \mathrm{kg}_{\text {trip }}{ }^{-1}$ or $0.17(\mathrm{SE}=0.08)$ ind trip $^{-1}$. The CPUE of live brownmarbled grouper was still low until December 2013 (Figure 5).

Most brown-marbled grouper caught between March and June 2013 were close to the release sites (Figure 6). In March 2013, most of 


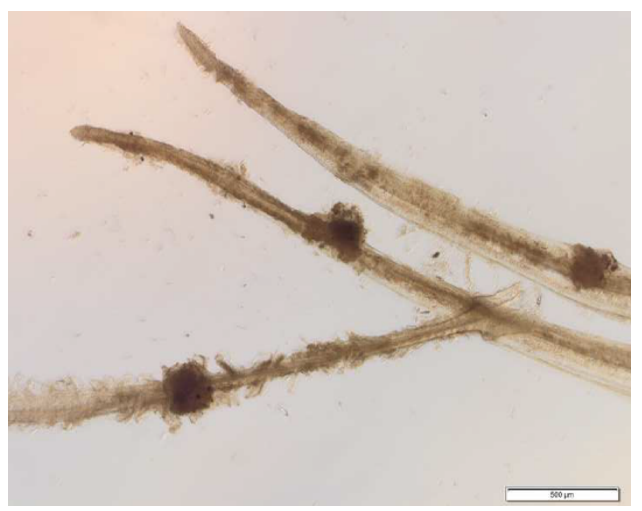

Figure 7: The cysts recorded in the gill filaments of cultured brown-marbled grouper.

brown-marbled groupers were caught at the deep reef of Cemara Kecil Island (around 0.6-1 km from the release site of Cemara Kecil Island), Terusan (around $2.7 \mathrm{~km}$ from the release site Taka Malang), Nyamplungan (around $1.2 \mathrm{~km}$ from the release site Taka Malang), Alang-alang (around $2.3 \mathrm{~km}$ from the release site Taka Malang) and Tanjung Gelam (around $2.3 \mathrm{~km}$ from the release site Taka Malang). In April 2013, most of brown-marbled groupers were caught at deep reef of Cemara Kecil Island, Cemara Besar Island (around $2.6 \mathrm{~km}$ from the release site of Cemara Kecil Island) and Tanjung Gelam. In May 2013, fishing grounds of brown-marbled grouper that were near the release sites were Alang-alang and Tanjung Gelam. In June 2013, several brown-marbled groupers also were caught close to the release site; Tanjung Gelam. Between July and December 2013, the fishing grounds of brown-marbled groupers were farther than the fishing ground between March and June 2013. Most of the brown-marbled groupers were caught at the southern part of Karimunjawa Island, Menjangan Besar Island, and Menjangan Kecil Island, which are located 7-9 $\mathrm{km}$ from the release site in Cemara Kecil Island or 8-11 km from the release site in Taka Malang. Although a high CPUE was recorded between March and June 2013 and most of the fish were caught close to the release sites, this could not be attributed to the stock enhancement since only one tagged brown-marbled grouper was recorded in March 2013 which was released again by the fisherman.

\section{Parasite}

We examined 35 brown-marbled grouper to investigate the ectoand endoparasite that could be brought by cultured brown-marbled grouper from mariculture facility to the natural population. No metazoan parasite species was found in cultured brown-marbled grouper; we only found some cysts that were attached to the fins and gill. The cysts were white and had a rounded shape, $120-200 \mu \mathrm{m}$ in diameter (Figure 7) at a prevalence of $45.71 \%$. We could not identify the cause of these cysts even under high magnification.

\section{Discussions}

\section{Risks}

Several studies on the potential risks of releasing fish to enhance the natural populations have been conducted in order to improve the restocking, stock enhancement, and sea-ranching programmes. The greatest difficulty to release juvenile fish to the natural population is predation. Blankenship and Leber [33] and Bartley and Bell [34] applied field experiments to identify the methods and techniques to significantly reduce the predation rate. Kurnia [19] investigated the minimum size of sea ranched brown-marbled grouper in the Seribu Islands, Indonesia. Based on the catch history he assumed that the minimum size of brown-marbled grouper to survive from predator is $10 \mathrm{~cm}$. Moreover, the Ministry of Marine Affairs and Fisheries produced a guideline for stock enhancement for marine fish mentioning that the minimum size of fish is $10 \mathrm{~cm} \mathrm{[23].}$

Contradictory to Kurnia [19] and MMAF [23], this study demonstrates that $10 \mathrm{~cm}$ of fingerling size brown-marbled grouper is too small for release at Karimunjawa Islands due to the lack of preadaption and appropriate avoidance reaction to predators. Based on our observation, brown-marbled grouper at $10 \mathrm{~cm}$ cannot adapt directly at the condition under presence of predators, and need at least 2-3 days before they actively search for shelter. Slow adaptation of the released fish to the natural environment is caused by less learning opportunities under cultivation conditions, because the fish are kept in a plain and homogenous cultivation tank in the mariculture facility [35]. Moreover, the natural camouflage with cryptic ability usually exhibited by brownmarbled grouper [36] was less well developed on the released fish, which adds to the inadequate behaviour of the $10 \mathrm{~cm}$ fish.

Education and awareness of the fishermen to protect the released fish are important for any stock enhancement program, allowing them to reach suitable size [37]. The release of cultured brown-marbled grouper in the no-take zones and protected zones was appropriate in the view of them from fisheries activities. However, this cannot prevent grouper migrating to non-protection zones. It appears to be better to release the fingerling fish in an area with limited migration possibilities, leading to a better protection e.g. at Cemara Kecil Island. However, our experiment demonstrates that released brown-marbled groupers were already caught by fisherman before they had reached a suitable size one month after the release, although we released the fish into the no-take and protection zone with limited migration area. It was not prevented that the fish was caught by fishermen before reaching a suitable size. Outreach to the fishermen community can reduce the risk of exploitation, and fisheries pressure. One fisherman who caught a brown-marbled grouper with tag in March 2013 released it again, knowing stock enhancement programme. Community support on national park management including self-fishing regulation influences the management effectiveness and the grouper fish stock [22,38]. Tringali et al. [39] already recommend that to optimally succeed, it be not only by providing information to society (fishermen community) but also developing the institutional capacity, possibly involving them in the stock enhancement programme.

Another risk, not apparent in the present study, is the potential transfer of parasites. The cultured grouper from mariculture potentially carry parasites and may transfer these to other wild fish [40-42], potentially causing a problem to the natural population. E. fuscoguttatus in Indonesia harbours a rich parasite community, including 1 protozoan, 4 monogeneans, 1 hirudinean, 1 copepod, 4 isopods, 1 microsporean, 2 myxozoans, 10 digeneans, 4 cestodes, 9 nematodes and 2 acanthocephalans [41-42]. Based on our investigation to 35 fish, we did not find any metazoan parasites, due to the original cultivation conditions inside the farm; however, we recorded cysts in the gills and fins of the fish, of undetermined origin. Such cysts can be caused by single celled parasites or fungi. Mariculture facilities that create controlled cultivation conditions and implement the codes to prevent the cause of high mortality of the cultured fish caused by parasite - can reduce the risk of parasite transfer to wild populations [14]. Rücker et al. [41] could not find the ectoparasites on cultured 
Citation: Yulianto I, Hammer C, Wiryawan B, Palm HW (2015) Potential and Risk of Grouper (Epinephelus spp., Epinephelidae) Stock Enhancement in Indonesia. J Coast Zone Manag 18: 394. doi: 10.4172/2473-3350.1000394

Page 7 of 9

\begin{tabular}{|c|c|c|c|c|}
\hline No & Species & Number of fish & Size $(\mathrm{cm})$ & Province \\
\hline 1 & Epinephelus fuscoguttatus & 4,000 & - & Kepulauan Riau \\
\hline 2 & Epinephelus fuscoguttatus & 3,500 & 9 & DKI Jakarta \\
\hline 3 & Cromileptes altivelis & 6,500 & 7 & Central Java \\
\hline 4 & Epinephelus fuscoguttatus & 6,000 & - & Central Java \\
\hline 5 & Grouper & 6,700 & - & East Kalimantan \\
\hline 6 & Epinephelus fuscoguttatus & 17,000 & $5-12$ & Central Sulawesi \\
\hline 7 & Epinephelus fuscoguttatus & 12,500 & $3-4$ & Gorontalo \\
\hline 8 & Cromileptes altivelis & 15,000 & $3-4$ & North Maluku \\
\hline 9 & Grouper & 75,000 & $5-8$ & North Sumatera \\
\hline 10 & Epinephelus fuscoguttatus & 5,000 & 8 & Bali \\
\hline 11 & Grouper & 5,000 & 8 & Bali \\
\hline 12 & Cromileptes altivelis & 5,000 & $3-5$ & Bangka Belitung \\
\hline 13 & Epinephelus fuscoguttatus & $\sim 30,000$ & - & North Sulawesi \\
\hline 14 & Epinephelus fuscoguttatus & 6,250 & 3 & West Java \\
\hline \multirow[t]{2}{*}{15} & Grouper & 2,500 & 3 & North Sulawesi \\
\hline & Total & 199,950 & & \\
\hline
\end{tabular}

Table 1: Grouper released during one man one thousand fries programme in 2011.

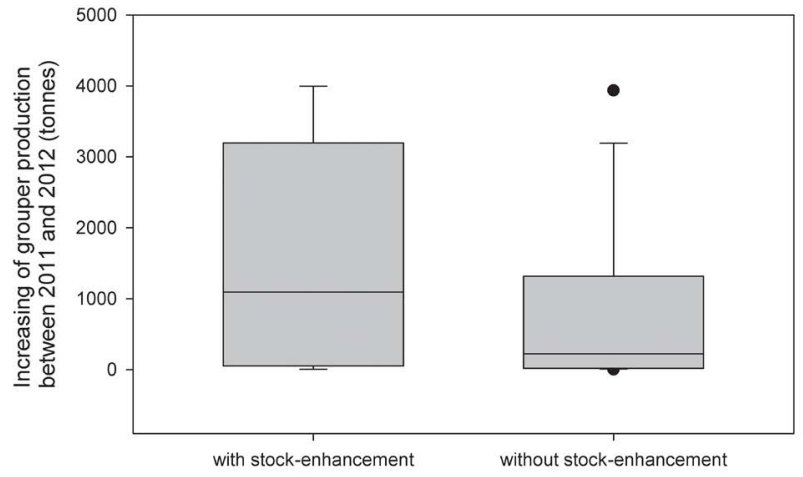

Figure 8: Box plot of the increasing of grouper production between 2011 and 2012 in the provinces in Indonesia, which were implemented with and without any stock enhancements.

brown-marbled grouper that had a length between 20.5 and $34.5 \mathrm{~cm}$, obtained from net cages in Lampung Bay. However, endoparasites were present. The observed low risks of parasite transfer in the present study cannot be generalized to all of the fish and circumstances, depending on the mariculture facility condition for the fingerlings.

\section{Potential and Progress of Grouper Stock Enhancement in Indonesia}

The Ministry of Marine Affairs and Fisheries of Indonesia announced that the grouper demand is increasing, leading to increase grouper production [43], and promoting the grouper production from aquaculture. However, the price of cultured grouper is lower than that of wild fish. The difference in price is caused by the buyers' perception on the different taste of cultured grouper and the relatively poor survival of cultured grouper during transportation from farm to market [44]. Although Rahmansyah [44] stated that the buyers' perception was not tested, Chan and Johnston [45] showed that more than $70 \%$ of respondents preferred wild caught fish, and in fact, the price of wild grouper catches is higher than the price of cultured grouper. Higher prices of the wild grouper catches certainly lead fishermen to still catch wild groupers and even fishermen increase the fishing effort under already overfished conditions. Increasing fishing effort to wild grouper leads to increase fishing pressure to the grouper habitats, and later on to the ecosystem [1]. Stock enhancement of grouper has a potential to lower the problems caused by the wild grouper catches. However, the availability of juveniles is one of the very important preconditions in stock enhancement [46]. The production of fingerling size of grouper in Indonesia increases significantly since 2001 and is sufficient, and supplies fingerling grouper demand around the world, even though sometimes the grouper fingerling production has a surplus production due to inconsistency of demand [47-48]. However, so far none of the production methodologies prepares the fish for a subsequent release into the wild, preparing them to survive and evade predation. This is a prerequisite for a successful use of the Indonesian fingerlings in stock enhancement programmes.

Stock enhancement for marine fish in Indonesia as part of "one man one thousand fries" programme was conducted by the release of snapper, milkfish, and grouper. The latter group, in particular, was released to enhance the yield and to fulfil the increasing demand. Selected species in 2011 were brown-marbled-grouper (Epinephelus fuscoguttatus) and Humpback grouper (Cromileptes altivelis). Around 199,950 juveniles were released into the wild in 12 provinces in Indonesia (Table 1) [49]. To evaluate the impact of grouper stock enhancement, we calculated the increasing grouper production between 2011 and 2012 in each province in Indonesia, and compared the difference of increasing grouper production between the provinces with and without stock enhancement. We chose the provinces that had a surplus grouper production between 2012 and 2011: 9 provinces that had implemented stock enhancement and 13 provinces that had not implemented stock enhancement programmes yet. Based on the box plot comparison (Figure 8) and the mean of the increasing grouper production between the provinces with and without stock enhancement, the stock enhancement did not significantly contribute ( $p>0.05$ ) to the increasing of grouper production. We assume that the size of released grouper contributed to the inefficiency of the stock enhancement programme in 2011. The size of grouper released in 2011 was from 3 to $12 \mathrm{~cm}$, with the median size of released grouper below $8 \mathrm{~cm}$. Our experiment demonstrates that predation becomes the main problem at a release of $10 \mathrm{~cm}$ of fingerling grouper (E. fuscoguttatus). Of course, the predation risk becomes even higher when the released grouper is below $8 \mathrm{~cm}$. Our experiment indicates that to decrease the predation risks and to optimise the impact to the grouper yield in grouper stock enhancement, the minimum size of brown-marbled grouper should be $15 \mathrm{~cm}$. Since the available size of cultured grouper in the mariculture centre is $10 \mathrm{~cm}$ or less, the cultured fish need to be kept 
Citation: Yulianto I, Hammer C, Wiryawan B, Palm HW (2015) Potential and Risk of Grouper (Epinephelus spp., Epinephelidae) Stock Enhancement in Indonesia. J Coast Zone Manag 18: 394. doi: 10.4172/2473-3350.1000394

in the net cages for several weeks to reach the size of $15 \mathrm{~cm}$. In addition, the cultivation technique in the farm for the fingerlings would require conditions that prepare the fish for a later release, e.g. by adding hiding places into the tanks, and larger sized fish might be more susceptible to transfer fish parasites from the farm into the wild [41].

Stock enhancement is relatively new and needs improvement especially concerning the applied methods and techniques [8]. Based on the lesson learned from the successful sea trout stock enhancement [50], the release of eggs or larvae of grouper could be another option to increase the success of stock enhancement. The release of eggs or larvae of grouper could be conducted at best at the spawning aggregation sites and during spawning season. Release during this life phase is expected to increase the learning ability of grouper, which is apparently reduced when larvae of grouper are grown inside a mariculture facility. An additional benefit is that the release of eggs or larvae is less costly. Another important measure is the development of the success indicators, as suggested by Palm and Stoye [51]. Underwater visual census, fish-catch monitoring and fish tags are among available methods to monitor the impact of grouper stock enhancement. However, the study found underwater visual census not to be an appropriate method to monitor the impact of stock enhancement. During the study, we did not find any brown-marbled groupers using underwater visual census but we recorded brown-marbled groupers from the fish-catch monitoring. It seems that the fish-catch monitoring is one of the appropriate methods to monitor the impact of grouper stock enhancement. As regards to the fish tags, more studies need to be conducted on the use of these in the stock enhancement research. Several other attempts on recapture tagged fish resulted in similarly low number of recaptured tagged fish [50,52-53]. Consequently, future stock enhancement programmes in Indonesia must be accompanied by clear success indicators, experimentally justify the juvenile release size and training condition, and might be supported with eggs and larvae release.

\section{Acknowledgments}

We wish to acknowledge the support provided by Balai Taman Nasional Karimunjawa for the great cooperation and hospitality during the fieldwork. We also thank Jamaluddin, Ripanto, T Kartawijaya, E Muttaqin and SAR Tarigan for helping the field research, $K$ Neubert and $S$ Theisen for helping parasite investigation, $P$ Ningtias for carefully reading the manuscript and providing useful inputs, and anonymous reviewers for their constructive comments. Special thanks to Wildlife Conservation Society for their support to the field research, and to Ministry of Education Indonesia-German Academic Exchange Service (IGSP-DAAD) for providing the scholarship.

\section{References}

1. Sadovy Y, Craig MT, Bertoncini AA, Carpenter KE, Cheung WWL, et al. (2013) Fishing groupers towards extinction: a global assessment of threats and extinction risks in a billion dollar fishery. Fish and Fisheries 14: 119-136.

2. Food and Agriculture Organization (2014) Fisheries and aquaculture software FishStatJ - software for fishery statistical time series. In: FAO Fisheries and Aquaculture Department.

3. Johnston B, Yeeting B (2006) Economics and marketing of the live reef fish trade in Asia-Pacific. Australian Centre for International Agricultural Research, Canberra.

4. Pet-Soede L, Horuodono H, Sudarsono (2004) SARS and the live food fish trade in Indonesia: some anecdotes. SPC Live Reef Fish Information Bulletin 12: 3-9.

5. Ministry of Marine Affairs and Fisheries (2002) Indonesian statistical data on capture fisheries and aquaculture. Ministry of Marine Affair and Fisheries, Jakarta.

6. Ministry of Marine Affairs and Fisheries (2013) Capture fisheries statistics of Indonesia, 2012. Ministry of Marine Affair and Fisheries, Jakarta.
7. Ministry of Marine Affairs and Fisheries (2010a) Ministerial Decree Number PER.06/MEN/2010 on the Strategic Planning of Ministry Marine Affair and Fisheries 2010-2014. Ministry of Marine Affair and Fisheries, Jakarta.

8. Bell JD, Leber KM, Blankenship HL, Loneragan NR, Masuda R (2008) A new era for restocking, stock enhancement and sea ranching of coastal fisheries resources. Review in Fisheries Science 16: 1-9.

9. Masuda R, Tsukamoto K (1998) Stock enhancement in Japan: review and perspective. Bulletin of Marine Science 62: 337-358.

10. Lorenzen K (2008) Understanding and managing enhancement fisheries system. Reviews in Fisheries Science 16: 10-23.

11. Loneragan NR, Ye Y, Kenyon RA, Haywood DE (2006) New directions for research in prawn (shrimp) stock enhancement and the use of models in providing directions for research. Fisheries Research 80: 91-100.

12. Kitada S, Kishino H (2006) Lessons learned from Japanese marine finfish stock enhancement programmes. Fisheries Research 80:101-112.

13. Brown C, Day RL (2002) The future of stock enhancement: lessons for hatchery practice from conservation biology. Fish and Fisheries 3: 79-94.

14. Bartley DM, Bondad-Reantaso MG, Subasinghe RP (2006) A risk analysis framework for aquatic animal health management in marine stock enhancement programmes. Fisheries Research 80: 28-36.

15. Liao IC (1997) Status, problem and prospects of stock enhancement in Taiwan. Hydrobiologia 352: 167-180.

16. Baskoro MS, Yusfiandayani R, Wahyuningrum PI (2008) Setnet technology and squids attractor: A development review in Indonesia. Buletin PSP 17: 267-273.

17. Panggabean AS, Mardlijah S, Pralampita WA (2010) Artificial reef for the stock enhancement of napoleon wrasse in Gili Labak, Sumenep. Ministry of Research and Technology. Jakarta.

18. Taurusman AA, Isdahartati, Isheliadesti, Ristiani (2012) Restocking and habitat restoration of sea cucumbers: status of seagrass ecosystem at the restocking sites in Pramuka and Kelapa Dua Islands, Kepulauan Seribu, Jakarta. Jurnal IImu Pertanian Indonesia 10: 1-5.

19. Kurnia R (2012) Restocking model of kerapu macan (Epinephelus fusgoguttatus) in sea ranching system in Semak Daun shallow water, Kepulauan Seribu. PhD Thesis. Bogor Agricultural University, Bogor.

20. Nababan MG, Munasik, Yulianto I, Kartawijaya T, Prasetia R, et al. (2010) Ecological Status of Karimunjawa National Park. Bogor: Wildlife Conservation Society Indonesia, Bogor.

21. Campbell SJ, Kartawijaya T, Prasetia R, Pardede ST (2010) Developing sustainable alternative livelihood programs: a pilot project on groupe mariculture in Karimunjawa. Wildlife Conservation Society Indonesia, Bogor.

22. Campbell SJ, Kartawijaya T, Yulianto I, Prasetia R, Cliffton J (2013) Comanagement approaches and incentives improve management effectiveness in Karimunjawa National Park, Indonesia. Marine Policy 41: 72-79.

23. Ministry of Marine Affairs and Fisheries (2010b) Guideline of one man one thousand fries. Ministry of Marine Affair and Fisheries, Jakarta.

24. Kartawijaya T, Shinta TP, Yusuf S, Mulyadi (2010) Spatial and temporal pattern in spawning aggregations of groupers (Serranidae) and napoleon wrasse (Labridae) in Karimunjawa National Park. Proceeding of the International Conference on Small Islands and Coral Reefs.

25. McClanahan TR, Graham NAJ, Wilson SK, Letourneur Y, Fisher R (2009) Effects of fisheries closure size, age, and history of compliance on coral reef fish communities in the western Indian Ocean. Marine Ecology Progress Series 396: 99-109.

26. Karkarey R, Kelkar N, Lobo AS, Alcoverro T, Arthur R (2014) Long-lived groupers require structurally stable reefs in the face of repeated climate change disturbances. Coral Reefs 33: 289-302.

27. Campbell SJ, Pardede S (2006) Reef fish structure and cascading effects in response to artisanal fishing pressure. Fisheries Research 79: 75-83.

28. Yulianto I, Prasetia R, Muttakin E, Kartawijaya T, Pardede ST, et al. (2012) Monitoring technical guideline of coral reef, seagrass, and mangrove ecosystem. Wildlife Conservation Society Indonesia, Bogor. 
Citation: Yulianto I, Hammer C, Wiryawan B, Palm HW (2015) Potential and Risk of Grouper (Epinephelus spp., Epinephelidae) Stock Enhancement in Indonesia. J Coast Zone Manag 18: 394. doi: 10.4172/2473-3350.1000394

29. Yulianto I, Hammer C, Wiryawan B, Kartawijaya T, Pardede ST, Palm HW (2014) Improvement of fish length estimate for underwater visual census of reef fish biomass. Journal of Applied Ichthyology 31: 308-314.

30. Palm HW (2011) Fish parasites as biological indicators in a changing world: can we monitor environmental impact and climate change? In: Mehlhorn, $\mathrm{H}$ (ed). Progress in parasitology, parasitology research monographs 2. SpringerVerlag Berlin, Heidelberg.

31. Cribb TH, Bray RA (2010) Gut wash, body soak, blender and heat-fixation: approaches to the effective collection, fixation and preservation of trematodes of fishes. Systematic Parasitology 76: 1-7.

32. Riemann F (1988) Nematoda. in Higgins RP, Thiel H. (Eds) Introduction to the study of meiofauna. Smithsonian Institution Press, Washington DC.

33. Blankenship HL, Leber KM (1995) A responsible approach to marine stock enhancement. American Fisheries Society Symposium 15: 167-175.

34. Bartley DM, Bell JD (2008) Restocking, stock enhancement, and sea ranching: arenas of progress. Review in Fisheries Science 16: 357-365.

35. Salvanes AGV, Moberg O, Ebbesson LOE, Nilsen TO, Jensen KH, et al. (2013) Environmental enrichment promotes neural plasticity and cognitive ability in fish. Proceedings of the Royal Society B 280: 1-7.

36. Pears RJ (2005) Comparative demography and assemblage structure of serranid fishes: implications for conservation and fisheries management. $\mathrm{PhD}$ Thesis. James Cook University, Townsville.

37. Matsuoka T (1989) Current state of affairs and problems facing sea-farming with emphasis placed on technical problems of fingerling production. International Journal of Aquaculture and Fisheries Technology 1: 324-332.

38. Yulianto I, Hammer C, Wiryawan B, Palm HW (2013) Fishing-induced Groupers Stock Dynamics in Karimunjawa National Park, Indonesia. Proceeding of the International Conference on Marine Science.

39. Tringali MD, Leber KM, Halstead WG, Mcmichael R, O'hop J, et al. (2008) Marine stock enhancement in Florida: A multi-disciplinary, stakeholdersupported, accountability-based approach. Reviews in Fisheries Science 16 51-57.

40. Rückert S, Klimpel S, Al-Quraishy S, Mehlhorn H, Palm HW (2009) Transmission of fish parasites into grouper mariculture (Serranidae: Epinephelus coioides (Hamilton, 1822)) in Lampung Bay, Indonesia. Parasitology Research 104: 523-532.

41. Rückert S, Klimpel S, Palm HW (2010) Parasites of cultured and wild brown- marbled grouper Epinephelus fuscoguttatus (Forsskål, 1775) in Lampung Bay, Indonesia. Aquaculture Research 41: 1158-1169.

42. Palm HW, Kleinertz S, Rückert S (2011) Parasite diversity as an indicator of environmental change? An example from tropical grouper (Epinephelus fuscoguttatus) mariculture in Indonesia. Parasitology 138: 1793-1803.

43. Directorate General of Aquaculture (2013) Government performance accountability report of Directorate General of Aquaculture, Ministry of Marine Affairs and Fisheries. Directorate General of Aquaculture, Ministry of Marine Affairs and Fisheries, Jakarta.

44. Rachmansyah, Usman, Palinggi NN, Williams K (2009) Formulated feed for tiger grouper grow-out. Network of Aquaculture Centers in Asia-Pacific.

45. Chan NWW, Johnston B (2007) Applying the triangle taste test to wild and cultured humpback grouper (Cromileptes altivelis) in the Hong Kong market. SPC Live Reef Fish Information Bulletin 17: 31-35.

46. Bell JD, Bartley DM, Lorenzen K, Loneragan NR (2006) Restocking and stock enhancement of coastal fisheries: Potential, problems and progress. Fisheries Research 80: 1-8.

47. Halwart M, Soto D, Arthur JR (2007) Cage aquaculture: Regional reviews and global overview. Food and Agricultural Organization, Rome.

48. Sugama K, Rimmer MA, Ismi S, Koesharyani I, Suwirya K, et al. (2013) Management of brown-marbled grouper juvenile (Epinephelus fuscoguttatus) The best guideline. Australian Centre for International Agricultural Research, Canberra.

49. Directorate of Fisheries Resources (2011) Evaluation of "One Man One Thousand Fries". Directorate of Fisheries Resources-Directorate General of Capture Fisheries, Ministry of Marine Affairs and Fisheries, Jakarta.

50. HELCOM (2011) Salmon and Sea Trout Populations and Rivers in the Baltic Sea - HELCOM assessment of salmon (Salmo salar) and sea trout (Salmo trutta) populations and habitats in rivers flowing to the Baltic Sea. Baltic Sea Environment Proceeding No. 126A.

51. Palm HW, Stoye S (2014) Report on criteria / methods for demonstrating the success of stock enhancement. Aquafima.

52. Bo ZL, Zhou WX (2002) Study on marking and enhancement of grouper Epinephelus. Journal of Zhejiang Ocean University 21: 321-326.

53. Egli DP, Moy W, Naisilisili W (2010) Fish movement in MPAs on coral reefs in Kubulau, Fiji. Wildlife Conservation Society Fiji, Suva. 